\title{
Uptake and release of zinc by aquatic bryophytes (Fontinalis antipyretica L. ex. Hedw.)
}

\author{
Ramiro J.E. Martins ${ }^{\mathrm{a}}$, Rui A.R. Boaventura ${ }^{\mathrm{b}, *}$ \\ a Department of Chemical Technology, Superior School of Technology, Polytechnic Institute of Bragança, Campus de Santa Apolónia, \\ 5301-857 Bragança, Portugal \\ ${ }^{\mathrm{b}}$ LSRE Laboratory of Separation and Reaction Engineering, Faculty of Engineering, University of Porto, Rua Dr. Roberto Frias, \\ 4200-465 Porto, Portugal
}

\begin{abstract}
The zinc uptake and posterior release by an aquatic bryophyte-Fontinalis antipyretica L. Ex Hedw. - was experimentally studied in laboratory exposing the plants to different zinc concentrations in the range, $1.0-5.0 \mathrm{mg} 1^{-1}$, for a $144 \mathrm{~h}$ contamination period, and then exposed to metal-free water for a $120 \mathrm{~h}$ decontamination period. The experiments were carried out in perfectly mixed contactors at controlled illumination, using mosses picked out in February 1997, with a background initial zinc concentration of $263 \mathrm{mg} \mathrm{g}^{-1}$ (dry wt.). A first-order mass transfer kinetic model was fitted to the experimental data to determine the uptake and release constants, $k_{1}$ and $k_{2}$, the zinc concentration in mosses at the end of the uptake period, $C_{\mathrm{mu}}$, and at the equilibrium, for the contamination and decontamination stages, $C_{\mathrm{me}}$ and $C_{\mathrm{mr}}$, respectively. A bioconcentration factor, $\mathrm{BCF}=k_{1} / k_{2}$ (zinc concentration in the plant, dry wt./zinc concentration in the water) was determined. A biological elimination factor defined as $\mathrm{BEF}=$ $1-C_{\mathrm{mr}} / C_{\mathrm{mu}}$ was also calculated. BCF decreases from about 4500 to 2950 as $\mathrm{Zn}$ concentration in water increases from 1.05 to $3.80 \mathrm{mg}^{-1}$. BEF is approximately constant and equal to 0.80 . Comparing $\mathrm{Zn}$ and $\mathrm{Cu}$ accumulation by Fontinalis antipyretica, it was concluded that the uptake rate for $\mathrm{Zn}\left(145 \mathrm{~h}^{-1}\right)$ is much lower than for $\mathrm{Cu}\left(628 \mathrm{~h}^{-1}\right)$ and the amount retained by the plant decreased by a factor of about seven. (C) 2002 Elsevier Science Ltd. All rights reserved.
\end{abstract}

Keywords: Aquatic bryophytes; Mosses; Kinetics; Zinc; Fontinalis antipyretica

\section{Introduction}

The quantitative determination of pollutants in the several compartments of aquatic ecosystems constitutes an important task for the identification of pollution sources, evaluation of contamination or decontamination trends and ecological quality control.

Aquatic mosses show a high capacity to assimilate nutrients, toxics organic compounds (e.g. pesticides) and heavy metals, leading to a concentration inside the plants several times higher than in the surrounding environment [1,2]. Due to their physiological and environmental characteristics and the fact they are widespread in most European rivers [3] aquatic mosses have been successfully used as biological indicators of surface waters (rivers, lakes) contamination by heavy metals [4-10]. Their accumulation capacity allows an integration of casual fluctuations in metal concentration in the water during long periods of time [11].

Particularly, aquatic bryophytes have been shown to satisfy the basic requisites for a good bioindicator [12], and so they can be used as a low cost methodology for monitoring water quality [8].

The accumulation capacity of aquatic mosses has been also explored to remove heavy metals from polluted waters $[13,14]$. 


\begin{tabular}{|c|c|c|c|}
\hline & & \\
\hline \multicolumn{2}{|c|}{$\begin{array}{l}\text { Nomenclature } \\
\mathrm{BCF} \quad \text { bioconcentration factor }\end{array}$} & & \\
\hline \multirow{4}{*}{\multicolumn{2}{|c|}{$\begin{array}{l}\mathrm{BEF} \text { biological elimination factor } \\
C_{\mathrm{m}} \text { metal concentration in the plant, } \mu \mathrm{gg}^{-1} \\
C_{\mathrm{m} 0} \text { initial metal concentration in the plant, } \\
\mu \mathrm{g} \mathrm{g}^{-1}\end{array}$}} & \multirow{5}{*}{$\begin{array}{l}C_{\mathrm{mu}} \\
C_{\mathrm{W}} \\
k_{1} \\
k_{2} \\
t_{\mathrm{d}} \\
\rho\end{array}$} & \multirow{5}{*}{$\begin{array}{l}\text { metal concentration in the plant at the end of } \\
\text { uptake period, } \mu \mathrm{g} \mathrm{g}^{-1} \\
\text { metal concentration in the water, } \mathrm{mg}^{-1} \\
\text { uptake rate constant, } \mathrm{h}^{-1} \\
\text { release rate constant, } \mathrm{h}^{-1} \\
\text { time at the end of uptake period, } \mathrm{h} \\
\text { water density, } \mathrm{kgl}^{-1}\end{array}$} \\
\hline & & & \\
\hline \multirow{2}{*}{$C_{\mathrm{m} 0}$} & & & \\
\hline & & & \\
\hline \multicolumn{2}{|c|}{$\mu \mathrm{gg}^{-1}$} & & \\
\hline
\end{tabular}

In order to get a correct and effective interpretation of biomonitoring results, several studies were carried out to establish heavy metal uptake and release kinetics either through laboratory experiments [9] or from field surveys [15].

Kinetics depends on several parameters concerning the plant itself and environmental factors (temperature, light intensity, metal concentration, presence of other compounds and physical-chemical water characteristics).

Heavy metal accumulation in bryophytes has been studied by several authors $[16,17]$ to elucidate the uptake and/or release mechanisms and the uptake rate from metal-enriched solutions.

Experimental results in batch systems suggest that two [18] or three stages [17] are identifiable during metal uptake by plant cells. However, in some cases, a global first-order mass transfer kinetic model corresponds to a sufficiently satisfactory approach [9].

The equilibrium concentration can be determined by exposing the plant to metal bearing water for a sufficiently long period until steady-state conditions are achieved. Alternatively, equilibrium concentration may be calculated from the uptake and release kinetic rate constants, experimentally determined by contaminating the plants during a short period and then exposing them to non-contaminated water [19].

This methodology was applied to determine bioconcentration factors of zinc by Gammarus pulex (L.) [20], and to investigate the uptake and release kinetics of copper by Fontinalis antipyretica [9].

Data from field [21] and laboratory [14] studies have shown that heavy metal uptake by aquatic bryophytes depends on the selected species. Laboratory experiments showed that the uptake of zinc by Rhynchostegium riparioides is higher than by Fontinalis antipyretica at least by a factor of two [22].

However, Fontinalis antipyretica has been recognized as a good bioindicator for heavy metal contamination, which is confirmed by several studies reported in literature [15]. Assuming an accidental discharge of a metal bearing effluent into a river, the knowledge of the uptake and release rates is essential to predict, after a short exposure period, the metal concentration in the water since metal concentrations in the bioindicator are known.

Moreover, it is possible, from those rates to verify if the elapsed time between the beginning of the discharge and the moss sampling for analysis is long enough to assume that equilibrium conditions were reached.

The main objective of this work is to study the uptake and release of $\mathrm{Zn}$ by an aquatic bryophyte-Fontinalis antipyretica-having in mind a future application of aquatic mosses to the decontamination of industrial effluents. Kinetic and equilibrium parameters will be determined by using a simple mass transfer model.

\section{Materials and methods}

\subsection{Mosses}

Experiments were carried out using an aquatic bryophyte, Fontinalis antipyretica (Hedw.) collected in the Selho River, at Aldão, in the Ave River basin. The samples were taken from a river stretch without metal contamination upstream, so the heavy metals present are assumed to be of natural origin. Mosses were rinsed in the sampling site, directly in the river water to remove sediments and invertebrates. In the laboratory the mosses were then washed with distilled water, selecting the plant green parts, which were kept for some hours in a refrigerator prior to starting the experiments. The mosses used in this experimental work were collected in February 1997.

\subsection{Experimental set-up}

The experimental set-up is a continuous flow system, including four 201 -rectangular $(250 \mathrm{~mm} \times 400 \mathrm{~mm})$ tanks in acrylic (Fig. 1). Water recirculation centrifugal pumps promote the agitation and homogenization in order to get perfectly mixed contactors, as confirmed by the analysis of the residence time distribution using the tracer $(\mathrm{KCl})$ technique. 
Each tank was supplied from a reservoir containing previously dechlorinated water (by adsorption of residual chlorine onto activated carbon), using peristaltic pumps. The metal solution was introduced in the feed line of each tank by a multi-channel peristaltic pump.

From a stock solution of $\mathrm{ZnCl}_{2}$, different zinc concentrations in the range $1.0-5.0 \mathrm{mgl}^{-1}$, were obtained in the tanks. Flow rate was set at $600 \mathrm{ml} \mathrm{min}^{-1}$ and the water level remained constant in the tanks. Experiments were carried out at ambient temperature, in the range $17-20^{\circ} \mathrm{C}$.

Illumination was supplied by two fluorescent lamps (a $40 \mathrm{~W}$ white light lamp and a $36 \mathrm{~W}$ rose light one) that remained switched on during all the experiments.

Lamps were about $0.9 \mathrm{~m}$ above water level and illumination at the surface registered an average value of $1723 \mathrm{~lx}$.

Moss samples in enough amounts for analyses in duplicate, were placed in parallelepiped plastic net bags and immersed in each tank. Experiments consisted of a contamination period of $144 \mathrm{~h}$ followed by a decontamination stage of $120 \mathrm{~h}$. Mosses and water samples were removed from each tank, at time intervals previously defined.

Biomass remained active during all the experiments as indicated by the oxygen bubbles release, due to photosynthesis. Although some plant growth could be expected it was negligible for the contact period within the tanks.

\subsection{Analytical procedures}

Moss samples from each tank were rinsed with distilled water and dried at $70^{\circ} \mathrm{C}$ for $24 \mathrm{~h}$. Then, they were ground in a steel-chromium rings mill at $1400 \mathrm{rpm}$ for $90 \mathrm{~s}$. Each moss sample was analyzed in duplicate after acid digestion. Approximately $100 \mathrm{mg}$ of moss were placed in boxes of teflon ( $23 \mathrm{ml}$ capacity) previously washed with $10 \% \mathrm{HNO}_{3}$ and then digested with $4 \mathrm{ml}$ of $65 \% \mathrm{HNO}_{3}$. Each box was inserted in a Parr bomb,

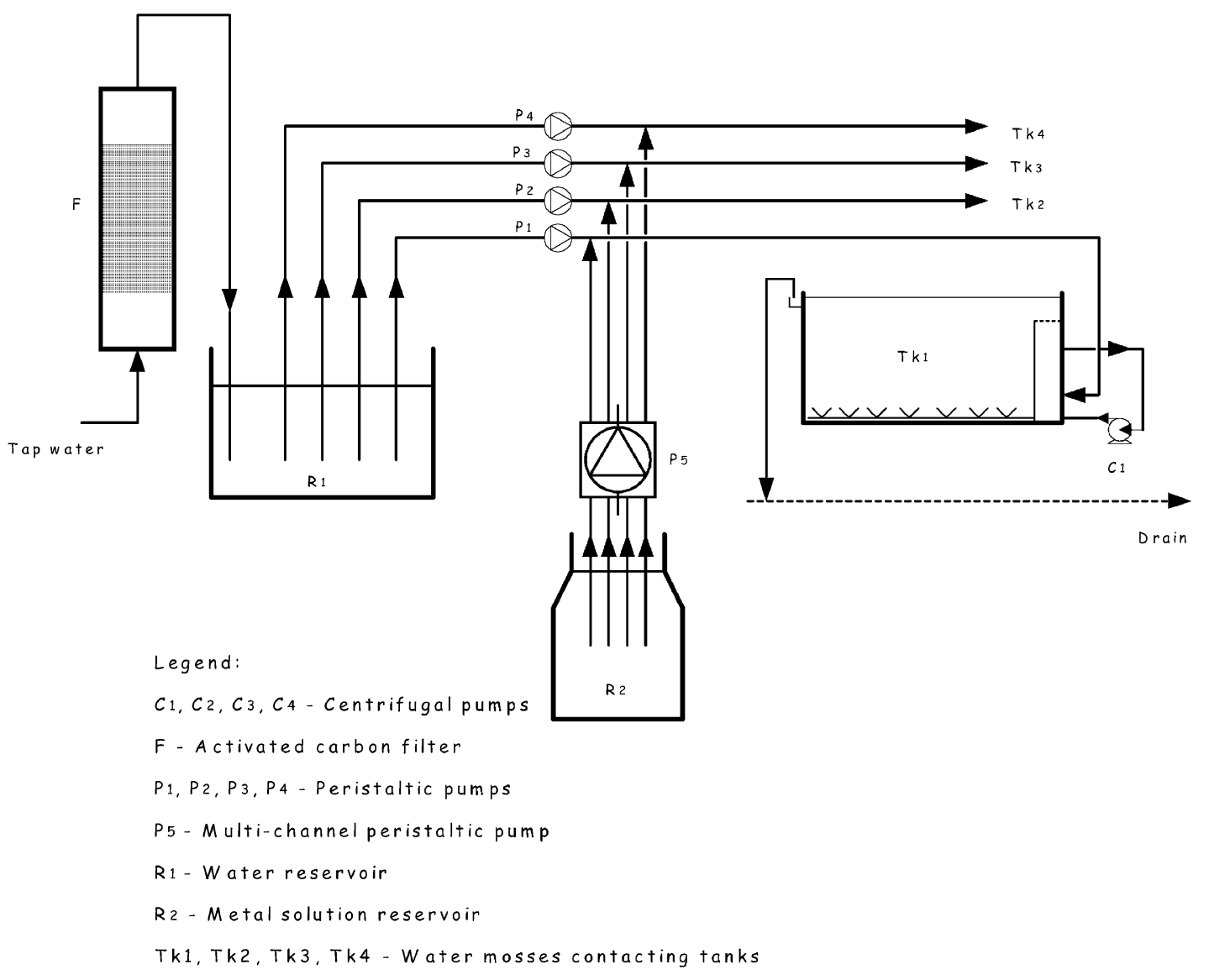

Fig. 1. Experimental set-up. 
which was placed in a microwave oven at $600 \mathrm{~W}$ for $60 \mathrm{~s}$. After digestion, the bomb was left to rest during $2 \mathrm{~h}$, being the solution transferred to a $25 \mathrm{ml}$ volumetric flask and diluted with distilled and deionized water. After vacuum filtration through a $0.45 \mu \mathrm{m}$ membrane, the solution was analyzed for zinc by atomic absorption spectrophotometry (AAS). The zinc content in mosses was expressed in $\mu \mathrm{gg}^{-1}$ dry weight.

\section{Kinetic model}

For a two-compartments system (water-plant), the metal ions transfer from and to aquatic bryophytes is assumed to be described by a first-order mass transfer model $[9,19]$, represented as

$C_{\mathrm{W}} \rightarrow_{k_{2}}^{k_{1}} C_{\mathrm{m}}-C_{\mathrm{m} 0}$,

where $C_{\mathrm{W}}$ is the metal concentration in the water, $\mathrm{mgl}^{-1}, C_{\mathrm{m}}$ the metal concentration in the plant, $\mu \mathrm{g} \mathrm{g}^{-1}$, $C_{\mathrm{m} 0}$ the initial metal concentration in the plant, $\mu \mathrm{g} \mathrm{g}^{-1}$, $k_{1}$ the uptake rate constant, $\mathrm{h}^{-1}, k_{2}$ the release rate constant, $\mathrm{h}^{-1}$.

The metal concentration variation in the plant along the uptake period is given by the differential equation:

$\frac{\mathrm{d} C_{\mathrm{m}}}{\mathrm{d} t}=k_{1} \frac{C_{\mathrm{W}}}{\rho}-k_{2}\left(C_{\mathrm{m}}-C_{\mathrm{m} 0}\right)$,

where $t$ is the time (h) and $\rho$ the water density $\left(\mathrm{kgl}^{-1}\right)$.

Integrating Eq. (2), with the initial condition $C_{\mathrm{m}}=$ $C_{\mathrm{m} 0}$ at $t=0$ and assuming $C_{\mathrm{W}}=$ constant, gives

$C_{\mathrm{m}}=C_{\mathrm{m} 0}+\frac{k_{1} C_{\mathrm{W}}}{k_{2} \rho}\left(1-\mathrm{e}^{-k_{2} t}\right)$.

When $t$ tends to $\infty$, the metal concentration in the plant tends to equilibrium $\left(C_{\mathrm{me}}\right)$, then

$C_{\mathrm{me}}=C_{\mathrm{m} 0}+\frac{k_{1} C_{\mathrm{W}}}{k_{2} \rho}$.

Replacing $t$ by $t_{\mathrm{d}} \quad\left(t_{d}=\right.$ time at the end of uptake period) in Eq. (3), we can calculate the metal concentration at the end of the contamination period $\left(C_{\mathrm{mu}}\right)$ :

$C_{\mathrm{mu}}=C_{\mathrm{m} 0}+\frac{k_{1} C_{\mathrm{W}}}{k_{2} \rho}\left(1-\mathrm{e}^{-k_{2} t_{\mathrm{d}}}\right)$

At steady-state conditions, the bioaccumulation rate may be represented by a bioconcentration factor (BCF) defined as

$\mathrm{BCF}=\frac{\left(C_{\mathrm{me}}-C_{\mathrm{m} 0}\right) \rho}{C_{\mathrm{W}}}=\frac{k_{1}}{k_{2}}$.
Interrupting the addition of metal to the water at $t=$ $t_{\mathrm{d}}$, a decontamination period starts up. Experimental studies have shown that in this period the metal elimination is not complete, i.e. the metal accumulated tends to a residual value greater than $C_{\mathrm{m} 0}$. In this phase, the metal concentration varies with time according to the equation:

$\frac{\mathrm{d} C_{\mathrm{m}}}{\mathrm{d} t}=-k_{2}\left(C_{\mathrm{m}}-C_{\mathrm{mr}}\right)$

where $C_{\mathrm{mr}}$ is the residual metal concentration in plant, $\mu \mathrm{g} \mathrm{g}^{-1}$.

Integrating Eq. (7) with the initial condition

$t=t_{\mathrm{d}} ; \quad C_{\mathrm{m}}=C_{\mathrm{mu}}$

it becomes

$C_{\mathrm{m}}=C_{\mathrm{mr}}+\left(C_{\mathrm{mu}}-C_{\mathrm{mr}}\right) \mathrm{e}^{-k_{2}\left(t-t_{\mathrm{d}}\right)}$.

As $t$ tends to $\infty, C_{\mathrm{m}}$ tends to $C_{\mathrm{mr}}$ and so a biological elimination factor (BEF) may be defined for the decontamination period:

$\mathrm{BEF}=\frac{C_{\mathrm{mu}}-C_{\mathrm{mr}}}{C_{\mathrm{mu}}}=1-\frac{C_{\mathrm{mr}}}{C_{\mathrm{mu}}}$.

The BEF can take values between zero (no decontamination when mosses are exposed to metal-free water) and one (total metal release).

\section{Results and discussion}

Table 1 shows the physico-chemical characteristics of the dechlorinated tap water throughout the experimental work. The evolution of zinc concentration in the tanks can be observed in Fig. 2. The initial zinc concentration in the mosses was $263 \mu \mathrm{g} \mathrm{g}^{-1}$, which can be considered the background concentration for aquatic mosses at non-polluted sites [23].

Table 1

Water quality parameters throughout the experimental work

\begin{tabular}{ll}
\hline Parameter & Range \\
\hline $\mathrm{pH}$ & $6.5-7.0$ \\
Conductivity $\left(\mu \mathrm{S} \mathrm{cm}^{-1}\right)$ & $220-240$ \\
Alkalinity $\left(\mathrm{mg} \mathrm{CaCO}_{3} \mathrm{l}^{-1}\right)$ & $50.0-58.2$ \\
Total hardness $\left(\mathrm{mg} \mathrm{CaCO}_{3} 1^{-1}\right)$ & $95.5-106.0$ \\
Nitrates $\left(\mathrm{mg} \mathrm{l}^{-1}\right)$ & $2.3-2.5$ \\
Chloride $\left(\mathrm{mg} \mathrm{l}^{-1}\right)$ & $13.4-13.8$ \\
Zinc $\left(\mathrm{mg} \mathrm{l}^{-1}\right)$ & $<0.03$ \\
TOC $\left(\mathrm{mg} \mathrm{l}^{-1}\right)$ & $14.4-14.7$ \\
\hline
\end{tabular}


Experimental data for the accumulation stage were fitted to Eq. (3) to determine the kinetic constants $k_{1}$ and $k_{2}$. The metal concentration at equilibrium, $C_{\mathrm{me}}$, and the metal concentration at the end of the uptake period, $C_{\mathrm{mu}}$, were calculated using Eqs. (4) and (5), respectively. Fitting the experimental data of the decontamination period to Eq. (8) it was determined the residual metal concentration, $C_{\mathrm{mr}}$. Table 2 shows the values of the kinetic constants and the equilibrium concentrations, both at the uptake and release stages. The evolution of the zinc concentration as predicted by the model, as well as the experimental values are plotted in Fig. 3.

The kinetic constant $k_{1}$, decreased from 145 to $59 \mathrm{~h}^{-1}$ as metal concentration increased from 1.05 to $3.80 \mathrm{mgl}^{-1}$, which suggests a toxic effect on the plant that reduces the metal uptake rate by the cells. Plant uptake capacity, expressed as $C_{\mathrm{me}}$ or $C_{\mathrm{mu}}$, increases with metal concentration in water (Table 2). A limit to the amount of metal bound by the plant seems to exist, as the maximum amount of metal retained by the plant depends on the number of binding sites. At the end of the 144-h-contamination period, the maximum uptake capacity was not achieved for the metal concentration range used in this work. Uptake kinetics, however, are not dependent on the number of binding sites, but on

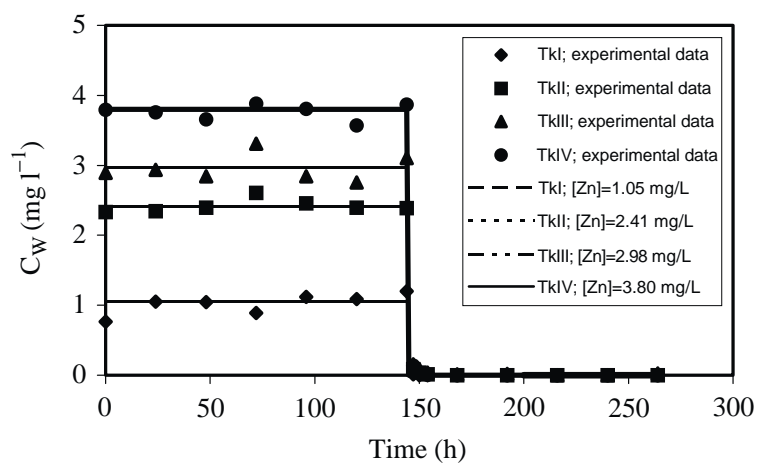

Fig. 2. Zinc concentration in the tanks throughout the experiment.

Table 2

Kinetic constants and equilibrium concentrations for zinc uptake and release

\begin{tabular}{llllll}
\hline $\begin{array}{l}C_{\mathrm{W}} \\
\left(\mathrm{mg}^{-1}\right)\end{array}$ & $\begin{array}{l}k_{1} \\
\left(\mathrm{~h}^{-1}\right)\end{array}$ & $\begin{array}{l}k_{2} \\
\left(\mathrm{~h}^{-1}\right)\end{array}$ & \multicolumn{1}{l}{$\begin{array}{l}C_{\mathrm{me}} \\
\left(\mu \mathrm{gg}^{-1}\right)\end{array}$} & $\begin{array}{l}C_{\mathrm{mr}} \\
\left(\mu \mathrm{g} \mathrm{g}^{-1}\right)\end{array}$ & $C_{\mathrm{mr}} / C_{\mathrm{mu}}$ \\
\hline 1.05 & 145 & 0.032 & 5030 & 656 & 0.13 \\
2.41 & 85 & 0.025 & 8447 & 1288 & 0.16 \\
2.98 & 82 & 0.025 & 10035 & 1455 & 0.15 \\
3.80 & 59 & 0.020 & 11459 & 2342 & 0.22 \\
\hline
\end{tabular}

$C_{\mathrm{W}}$, so the decrease in the kinetic constant $k_{1}$ as $C_{\mathrm{W}}$ increases suggests a toxic effect on the plant. For the decontamination phase, $k_{2}$ shows a similar behavior although in a lesser extent. At equilibrium the zinc concentration in plant increases, as could be expected, with the concentration in water. After decontamination, the residual zinc concentration in equilibrium with metal-free water is also proportional to the amount accumulated at the end of the uptake period.

In all cases, the $\mathrm{Zn}^{2+}$ uptake increased rapidly in the first hours and remained nearly constant after $100 \mathrm{~h}$ of accumulation, suggesting that bioaccumulation is a very fast process and about $85 \%$ of the total uptake is reached within $100 \mathrm{~h}$. This behavior is compatible with the mechanism of the uptake in three stages. The first stage (exchange adsorption) corresponds to a rapid surface binding; a large amount of zinc is taken up in this stage and it is limited to the Donnan-free-space of the cell wall [17]. The second stage is slower and it is the intracellular diffusion (penetration into the protoplast including the cell organelles) that governs the process. The slow third stage results from the active accumulation of metal within the plant cells. This stage is dependent upon factors that affect the metabolism, such as temperature and light intensity. Experimental results and model fitting show that the contribution of the two last stages compared with the first one can be neglected as regards uptake kinetics.

Comparing the theoretical equilibrium concentrations and the concentrations observed at the end of the accumulation phase, the period of $144 \mathrm{~h}$ was suitably chosen. The extent of the decontamination period lasts more than $120 \mathrm{~h}$, which it is evidenced in Fig. 3.

Table 3 shows the values of the $\mathrm{BCF}$ and $\mathrm{BEF}$ calculated from Eqs. (6) and (10), respectively. BCF values ranged between 4531 and 2950, and they vary in inverse relation to the zinc concentration in the water. For lower zinc concentrations $\left(1.052 \mathrm{mg}^{-1}\right)$, the mosses can accumulate approximately 4500 times more than the zinc concentration in the water. In the working range of zinc concentration in water it was observed an exponential relationship between $\mathrm{BCF}$ and $C_{\mathrm{W}}$ (Fig. 4):

$$
\begin{aligned}
\mathrm{BCF}= & 4600.9^{*} C_{\mathrm{W}}^{-0.3281}\left(r^{2}=0.99\right) \\
& \text { for } 1.05<C_{\mathrm{W}}<3.80 \mathrm{mg} \mathrm{l}^{-1} .
\end{aligned}
$$

In the decontamination period, the zinc released by the aquatic mosses reached high values. The BEF remained approximately constant and averaged 0.80 . The fraction of zinc retained by the plant at equilibrium with metalfree water $\left(C_{\mathrm{mr}} / C_{\mathrm{mu}}\right)$ increases with the maximum accumulated at the end of the uptake period $\left(C_{\mathrm{mu}}\right)$, as can observed in Table 2.

Exposing the aquatic moss Fontinalis antipyretica to a $0.6 \mathrm{mgl}^{-1}$ copper solution in similar conditions, Gonçalves and Boaventura [9] obtained a $\mathrm{Cu}$ concentration 

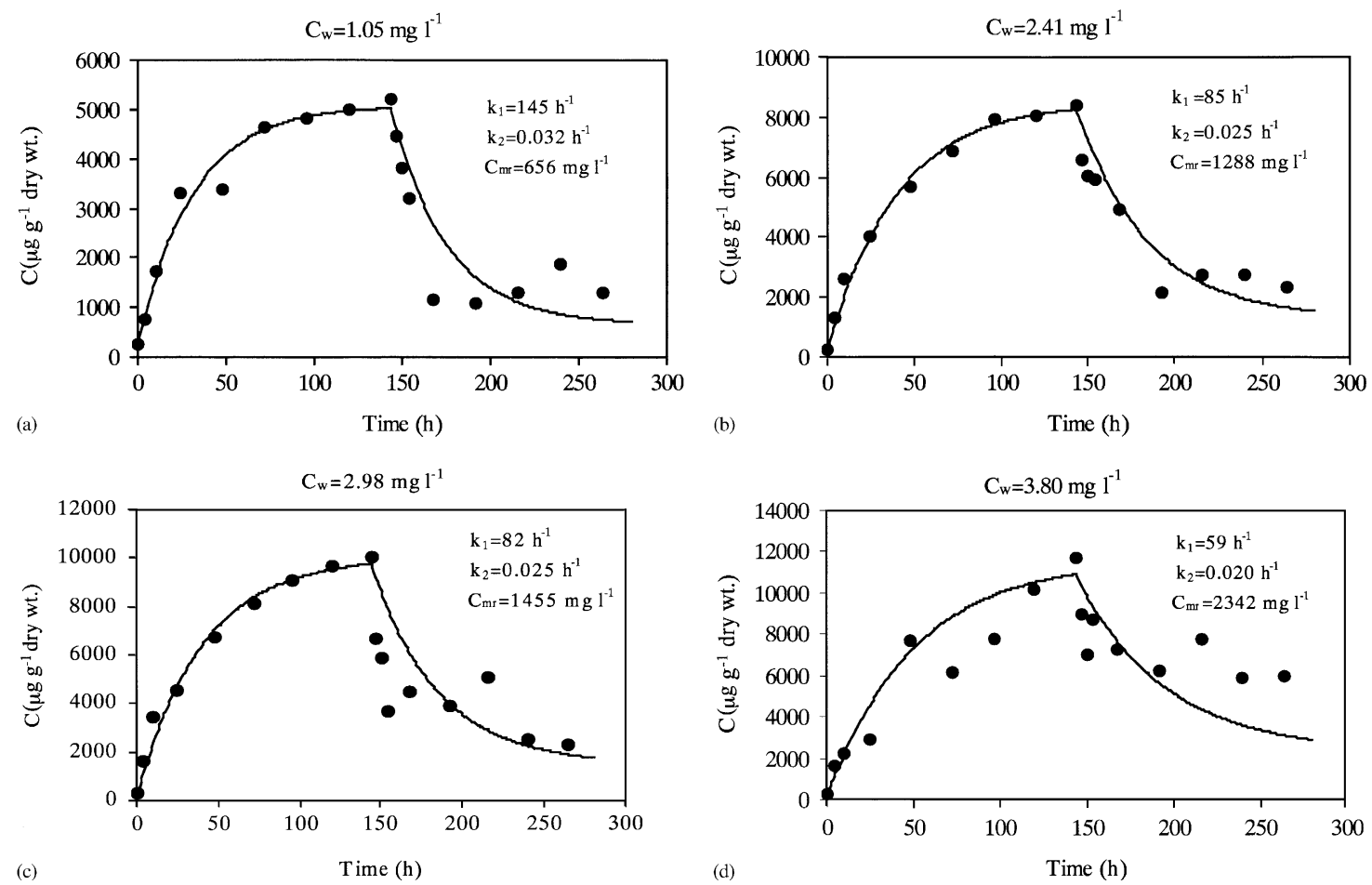

Fig. 3. Uptake and release of zinc by Fontinalis antipyretica for different metal concentrations in water: (a) $1.05 \mathrm{mg} \mathrm{l}^{-1}$, (b) $2.41 \mathrm{mg} 1^{-1}$, (c) $2.98 \mathrm{mgl}^{-1}$, (d) $3.80 \mathrm{mgl}^{-1}$ (一, model; $\bullet$, experimental data).

Table 3

Bioconcentration $(\mathrm{BCF})$ and biological elimination $(\mathrm{BEF})$ factors

\begin{tabular}{lll}
\hline$C_{\mathrm{W}}\left(\mathrm{mg} \mathrm{l}^{-1}\right)$ & BCF & BEF \\
\hline 1.05 & 4531 & 0.87 \\
2.41 & 3400 & 0.84 \\
2.98 & 3280 & 0.85 \\
3.80 & 2950 & 0.78 \\
\hline
\end{tabular}

at equilibrium equal to $18876 \mu \mathrm{g}$ per gram of moss (dry wt.), a value much higher than that found in this study using a $1.05 \mathrm{mgl}^{-1}$ zinc solution $(5030 \mu \mathrm{g}$ per gram of moss, dry wt.). A low soluble organic matter content in the water used in the experiments with copper may be responsible for the higher uptake capacity obtained for this metal. The BCF for $\mathrm{Cu}$ and $\mathrm{Zn}$ are 31400 and 4531, respectively, which shows that Fontinalis antipyretica can accumulate $\mathrm{Cu}$ about seven times more than $\mathrm{Zn}$. The observed higher capacity to accumulate $\mathrm{Cu}$ is also in agreement with the results found by Al-Asheh and Duvnjak [24]. The uptake rate, $k_{1}$, for $\mathrm{Cu}\left(628 \mathrm{~h}^{-1}\right)$ is largely higher than for $\mathrm{Zn}\left(145 \mathrm{~h}^{-1}\right)$. Part of the

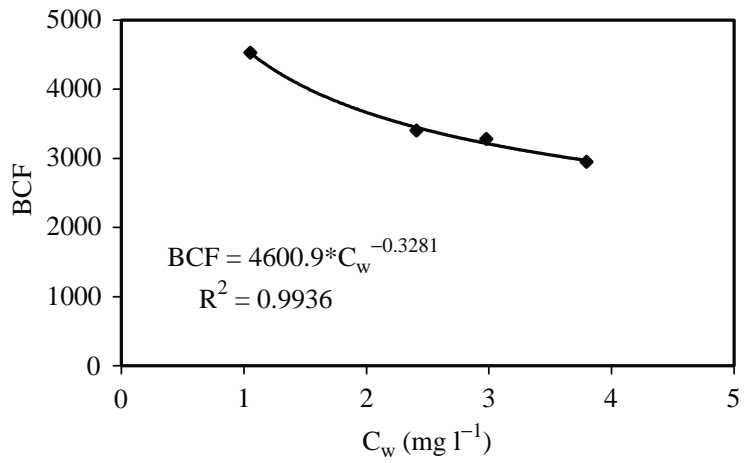

Fig. 4. Exponential relationship between the bioconcentration factor $(\mathrm{BCF})$ and the zinc concentration in water $\left(C_{\mathrm{W}}\right)$.

difference can be attributed to the lower concentration of $\mathrm{Cu}$ in solution but anyway the accumulation of $\mathrm{Cu}$ in the plant is faster. On the contrary, the desorption rate, $k_{2}$, for $\mathrm{Cu}$ is lower than for $\mathrm{Zn}, 0.020$ and $0.032 \mathrm{~h}^{-1}$, respectively, i.e., $\mathrm{Cu}$ is more strongly retained by the plant. When exposing previously contaminated mosses 
to metal-free water, about $84 \%$ of $\mathrm{Zn}$ is released to water, whereas for $\mathrm{Cu}$ that value decreases to $60 \%$.

\section{Conclusions}

A first-order mass transfer model was fitted to the experimental data obtained during the uptake and release stages of $\mathrm{Zn}$ by aquatic mosses. This model satisfactorily describes both periods, permitting to calculate the kinetic constants and equilibrium concentrations.

For aqueous solutions of zinc in the concentration range $1.05-3.80 \mathrm{mgl}^{-1}$, results show that the aquatic moss Fontinalis antipyretica retains, at equilibrium, the metal ion by a factor 4531-2950 ( $\mathrm{Zn}$ concentration in the moss, $\mu \mathrm{gg}^{-1}$, dry wt./ $\mathrm{Zn}$ concentration in water, $\left.\mathrm{mgl}^{-1}\right)$.

The metal uptake rate tends to decrease as the $\mathrm{Zn}$ concentration in the water increases, suggesting a toxic effect in mosses and a subsequent deterioration of their physiological state.

Exposing contaminated mosses to zinc-free water, plants only retain, at the end of the decontamination period, about $13-20 \%$ of the metal previously accumulated, depending on the amount of zinc retained by plants at the end of the uptake period.

Comparing $\mathrm{Zn}$ and $\mathrm{Cu}$ accumulation and release by the same moss species, it was observed that, for similar concentrations in water, $\mathrm{Zn}$ uptake is slower and the amount retained in the plant is lower, by a factor of about seven. On the other hand, $\mathrm{Zn}$ is more easily removed from the plant when contacting with clean water. So the performance of Fontinalis antipyretica as bioindicator for waters contaminated by zinc is not so good as for copper. Nevertheless this moss species may be used for monitoring aquatic systems where zinc is present as pollutant.

\section{Acknowledgements}

The authors wish to thank FCT (Portuguese Foundation for Science and Technology) for the financial support under the research project POCTI/C/EQU/ $12139 / 98$.

\section{References}

[1] Wehr JD, Whitton BA. Accumulation of heavy metals by aquatic mosses. 2. Rhynchostegium riparioides. Hydrobiologia 1983;100:261-84.

[2] Reddy KR, De Busk WF. Nutrient removal potential of selected aquatic macrophytes. J Environ Qual 1985;14:459-62.
[3] Whitton BA, Say PJ, Wehr JD. Use of plants to monitor heavy metals in rivers. In: Say PJ, Whitton BA, editors. Heavy metals in Northern England: environmental and biological aspects. England: University of Durham, 1981.

[4] Mouvet C. Accumulation of chromium and copper by the aquatic moss Fontinalis antipyretica L. ex. Hedw. transplanted in a metal-contaminated river. Environ Technol Lett 1984;5:541-8.

[5] Mouvet C. The use of aquatic bryophytes to monitor heavy metal pollution of freshwaters as illustrated by case studies. Verh Int Ver Limnol 1985;22:2420-5.

[6] Kelly MG, Girton C, Whitton BA. Use of moss-bags for monitoring heavy metals in rivers. Water Res 1987;21(11):1429-35.

[7] Gonçalves EPR, Boaventura RAR, Mouvet C. Sediments and aquatic mosses as pollution indicators for heavy metals in the Ave river basin (Portugal). Sci Total Environ 1992;114:7-24.

[8] Glime JM, Keen RE. The importance of bryophytes in a man-centered world. J Hattori Bot Lab 1984;55: 133-46.

[9] Gonçalves EPR, Boaventura RAR. Uptake and release kinetics of copper by the aquatic moss Fontinalis antipyretica. Water Res 1998;32(4):1305-13.

[10] Vincent CD, Lawlor AJ, Tipping E. Accumulation of Al, $\mathrm{Mn}, \mathrm{Fe}, \mathrm{Cu}, \mathrm{Zn}, \mathrm{Cd}$ and $\mathrm{Pb}$ by the bryophyte Scapania undulata in three upland waters of different $\mathrm{pH}$. Environ Pollut 2001;114:93-100.

[11] Whitehead NE, Brooks RR. Aquatic bryophytes as indicators of uranium mineralisation. Bryologist 1969;72:501-7.

[12] Philips DJH. The preliminary selection of an indicator organism. In: Quantitative aquatic biological indicators. London: Applied Science Publishers Ltd., 1980. p. 16-7.

[13] Jain SK, Vasudevan P, Jha NK. Removal of some heavy metals from polluted water by aquatic plants: studies on duckweed and water. Velvet Biol Wastes 1989;28:115-26.

[14] Srivastav RK, Gupta SK, Nigam KDP, Vasudevan P. Treatment of chromium and nickel in wastewater by using aquatic plants. Water Res 1994;28:1631-8.

[15] Mersch J, Kass M. La mousse aquatique Fontinalis antipyretica comme traceur da la contamination radioactive de la Moselle en aval da la Centrale nucléaire de Cattenom. Bull Soc Nat Luxemb 1994;95:109-17.

[16] Brown DH, Beckett RP. Intracellular and extracellular uptake of cadmium by the moss Rhytidiadelphus squarrosus. Ann Bot 1985;55:179-88.

[17] Pickering DC, Puia IL. Mechanism for the uptake of zinc by Fontinalis antipyretica. Physiology 1969;22:653-61.

[18] Foulquier L, Hébrard JP. Étude expérimentale de la fixation et de la décontamination du sodium 22 par une mousse dulcaciquole Platyhypnydium riparioides (Hedw.). Dix. Oecol Plant 1976;11(3):267-76.

[19] Walker CH. Kinetic models to predict bioaccumulation of pollutants. Funct Ecol 1990;4:295-301.

[20] $\mathrm{Xu} \mathrm{Q}$, Pascoe D. The bioconcentration of zinc by Gammarus pulex (L.) and the application of a kinetic model to determine bioconcentration factors. Water Res 1993;27(11):1683-8.

[21] Say PJ, Harding JPC, Whitton BA. Aquatic mosses as monitors of heavy metal contamination in the River 
Etherow, Great Britain. Environ Pollut Ser B 1981;2:295307.

[22] Wehr JD. Accumulation of heavy metals by aquatic bryophytes in streams and rivers in Northern England. $\mathrm{PhD}$ thesis, University of Durham, 1983. $432 \mathrm{pp}$.

[23] Gonçalves EPR, Soares HMVM, Boaventura RAR, Machado AASC, Silva JCGE. Seasonal variations of heavy metals in sediments and aquatic mosses from the Cávado river basin (Portugal). Sci Total Environ 1994;142:143-56.

[24] Al-Asheh S, Duvnjak Z. Adsorption of metal ions by moss. Adv Environ Res 1997;1(2):194-210. 